\title{
The Heart in Friedreich's Ataxia
}

\author{
RICHARD L. HEWER ${ }^{\star}$ \\ From the Department of Neurology, The Radcliffe Infirmary, Oxford
}

It has been known for many years that the heart is frequently abnormal in Friedreich's ataxia. Russell in 1946 reported in detail the histological findings in the hearts of four cases.

Since Russell's paper further reports have been published. Three of these (Nadas, Alimurung, and Sieracki, 1951; James and Fisch, 1963; Ivemark and Thorén, 1964) mentioned narrowing of the small cardiac arteries. Nadas et al. (1951) examined the heart of a child aged 16 who died suddenly after an upper respiratory tract infection. The heart was enlarged and there was extensive fibrosis and fatty degeneration of the myocardium. The coronary arteries showed medial hypertrophy and intimal proliferation which resulted in considerable narrowing of the lumen. James and Fisch (1963) examined the heart of a man aged 20 who died after a four-month period of heart failure. The heart weighed $550 \mathrm{~g}$. and showed interstitial fibrosis, focal degeneration of muscle fibres, and some cellular infiltration. In addition, there was extensive disease of the cardiac arteries-particularly those of 100$300 \mathrm{~m} \mu$ in diameter. Similar changes were found in the smaller pulmonary arteries. The arteries showed degeneration of the media and intimal hyperplasia. Ivemark and Thorén (1964) reported their findings in four further hearts from patients aged $21 ; 29,33$, and 50 years of age. All showed hypertrophy of the ventricular muscle and interstitial fibrosis. In addition, the large and medium arteries "showed patchy, subintimal fibrosis. In places narrowing of the lumen had been produced. Graham (1964) reported the findings in a child who died at the age of 6 after having an attack of severe cardiac pain. An electrocardiogram showed the changes of acute coronary insufficiency. Histological examination of the heart showed no evidence of disease in any of the cardiac vessels. There was no evidence of-myocardial infarction, though the heart did show severe myocardial fibrosis and a small

Received April 22, 1968

^ Present adq̣iress: Frenchay Hospital, Bristol. amount of cellular infiltration. J. W. C. Hagstrom (personal communication, 1967) reported arterial findings similar to those of James in three other hearts taken from patients dying with Friedreich's ataxia. It is to be noted that Russell (1946), in her careful report, does not mention any microscopical abnormality of the cardiac vessels.

The present study was undertaken in order to amplify the pathological data so far published and, in particular, to investigate the claims of some previous workers that extensive small artery disease is present in the heart.

\section{SuBJECTS AND METhodS}

Necropsy material has been obtained from many different centres in the United Kingdom. In most cases, necropsy was performed by a pathologist at a local hospital. Portions of the heart and nervous system were then sent to Oxford for examination. Two necropsies were performed in Oxford.

Necropsy details were available on 27 patients with Friedreich's ataxia. Portions of heart muscle from 13 patients were available for histological examination, and in addition three complete hearts were examined. In one additional case (C1), the cardiac and cord histology had been well described elsewhere (Urich, Norman, and Lloyd, 1957), but slides were not available to us. In 14 of these 17 cases sections of the spinal cord were studied. In 3 funther cases spinal cord sections were available but no heart material had been preserved.

There were 15 male and 12 female patients; 7 were 20 years or less at the time of death, 17 were between 21 and 40,2 were between 41 and 60 , and one was 70 .

In 18 patients death was due to uncomplicated heart failure (Table I). Three patients had diabetic ketosis and associated heart failure, and one died as a result of a cerebral embolism. One patient developed coma of uncertain cause terminally, and this was accompanied by atrial fibrillation. Thus, 23 patients showed clinical evidence of cardiac disorder before death. The cause of death was unknown in one -patient. Subarachnoid haemorrhage, pneumonia, and status epilepticus were the causes of death in the 3 remaining patients.

Of the 27 patients accepted for inclusion in the study, 26 fulfilled rigid neurological criteria. These included 
TABLE I

CLINICAL AND NECROPSY DETAILS OF 27 CASES

\begin{tabular}{|c|c|c|c|c|c|c|c|}
\hline \multirow{2}{*}{$\begin{array}{l}\text { Code } \\
\text { No. }\end{array}$} & \multirow{2}{*}{$\begin{array}{c}\text { Age at } \\
\text { death } \\
\text { (yr.) }\end{array}$} & \multirow{2}{*}{$\begin{array}{l}\text { Cardiac clinical } \\
\text { features }\end{array}$} & \multirow{2}{*}{$\begin{array}{l}\text { Electro- } \\
\text { cardiogram }\end{array}$} & \multicolumn{2}{|c|}{ Necropsy findings } & \multicolumn{2}{|c|}{ Histology } \\
\hline & & & & Heart & Other & Cord* & Heart \\
\hline $\mathrm{Cl}$ & 10 & $7 \mathrm{mth}$. heart failure & Abnormal & $255 \mathrm{~g}$. ; left ventricle & 一 & Usual & Fibrosis $t+$ \\
\hline $\mathrm{C} 2$ & 10 & $\begin{array}{l}7 \text { yr. transient heart fail- } \\
\text { ure; } 3 \text { days terminal } \\
\text { heart failure }\end{array}$ & Abnormal & Left ventricle enlarged & 一 & Usual & Fibrosis ++ \\
\hline $\mathrm{C} 3$ & 14 & $\begin{array}{l}5 \text { mth. atrial fibrillation; } \\
\text { terminal heart failure }\end{array}$ & Abnormal & $\begin{array}{l}460 \mathrm{~g} . ; \text { left ventricle en- } \\
\text { larged; thrombus in } \\
\text { left atrium }\end{array}$ & 一 & $\begin{array}{c}\text { No material } \\
\text { available }\end{array}$ & None \\
\hline $\mathrm{C4}$ & 16 & $\begin{array}{l}\text { Died suddenly while } \\
\text { cycling uphill }\end{array}$ & Abnormal & $\begin{array}{l}\text { Normal size; flabby } \\
\text { muscle }\end{array}$ & Pulmonary oedema & $\begin{array}{l}\text { No material } \\
\text { available }\end{array}$ & None \\
\hline $\mathrm{C5}$ & 16 & $\begin{array}{l}\text { No cardiac symptoms; } \\
\text { terminal subarachnoid } \\
\text { haemorrhage }\end{array}$ & Not taken & $\begin{array}{l}\text { Thrombus in left } \\
\text { atrium }\end{array}$ & $\begin{array}{l}\text { Ruptured intra- } \\
\text { cranial aneurysm }\end{array}$ & $\begin{array}{l}\text { No material } \\
\text { available }\end{array}$ & Fibrosis ++ \\
\hline C6 & 19 & $\begin{array}{l}\text { Sudden collapse, with fits, } \\
\text { vomiting, and pulmon- } \\
\text { ary oedema }\end{array}$ & $\begin{array}{l}\text { Normal } \\
\text { (age 7) }\end{array}$ & $\begin{array}{l}560 \mathrm{~g} \cdot ; \text { left and right } \\
\text { ventricles enlarged }\end{array}$ & $\begin{array}{l}\text { Pulmonary } \\
\text { oedema; con- } \\
\text { gested liver }\end{array}$ & Usual & $\begin{array}{l}\text { No material } \\
\text { available }\end{array}$ \\
\hline $\mathrm{C7}$ & 19 & $\begin{array}{l}4 \text { yr. angina; terminal } \\
\text { diabetic ketosis and } \\
\text { heart failure }\end{array}$ & Abnormal & $\begin{array}{l}\text { Left ventricle much } \\
\text { enlarged }\end{array}$ & & Usual & Fibrosis ++ \\
\hline $\mathrm{C} 8$ & 23 & $\begin{array}{l}18 \text { mth. atrial fibrillation; } \\
\text { heart failure for several } \\
\text { months }\end{array}$ & Abnormal & $\begin{array}{l}700 \mathrm{~g} \cdot ; \text { left ventricle } \\
\text { much enlarged }\end{array}$ & $\begin{array}{l}\text { Thrombus in left } \\
\text { renal artery }\end{array}$ & Usual & Fibrosis ++ \\
\hline C9 & 23 & $\begin{array}{l}2 \text { wk. pain in legs and } \\
\text { abdomen; terminal } \\
\text { atrial fibrillation, and } \\
\text { heart failure }\end{array}$ & Abnormal & $\begin{array}{l}\text { Normal size; thrombus } \\
\text { in left atrium }\end{array}$ & $\begin{array}{l}\text { Thrombus in com- } \\
\text { mon iliac arteries }\end{array}$ & Usual & Fibrosis ++ \\
\hline $\mathrm{C} 10$ & 23 & $\begin{array}{l}13 \text { yr. angina; terminal } \\
\text { appendicitis and low } \\
\text { output heart failure }\end{array}$ & Abnormal & $\begin{array}{l}400 \mathrm{~g} \text {; left ventricle } \\
\text { enlarged; thrombus } \\
\text { in right ventricle }\end{array}$ & 一 & Usual & $\begin{array}{l}\text { Fibrosis } t+\text {; } \\
\text { foci of } \\
\text { muscle }\end{array}$ \\
\hline C11 & 24 & $\begin{array}{l}\text { Terminal diabetic coma } \\
\text { and acute left ventricu- } \\
\text { lar failure }\end{array}$ & Abnormal & $\begin{array}{l}400 \mathrm{~g} . \text {; left ventricle en- } \\
\text { larged; thrombus in } \\
\text { right ventricle }\end{array}$ & 一 & Usual & $\begin{array}{l}\text { No material } \\
\text { available }\end{array}$ \\
\hline $\mathrm{C} 12$ & 24 & 1 yr. heart failure & Abnormal & $\begin{array}{l}525 \mathrm{~g} . ; \text { left and right } \\
\text { ventricles enlarged }\end{array}$ & - & $\begin{array}{l}\text { No material } \\
\text { available }\end{array}$ & $\begin{array}{l}\text { No material } \\
\text { available }\end{array}$ \\
\hline C13 & 27 & 4 yr. heart failure & Abnormal & $\begin{array}{l}730 \mathrm{~g} \cdot ; \text { left and right } \\
\text { ventricles enlarged }\end{array}$ & $\begin{array}{l}\text { Liver and lungs } \\
\text { congested }\end{array}$ & Usual & Fibrosis ++ \\
\hline C14 & 28 & 3 wk. heart failure & Abnormal & $\begin{array}{l}600 \mathrm{~g} . \text {; left ventricle en- } \\
\text { larged; thrombus in } \\
\text { right ventricle }\end{array}$ & & $\begin{array}{l}\text { No material } \\
\text { available }\end{array}$ & Fibrosis ++ \\
\hline $\mathrm{C15}$ & 29 & $\begin{array}{l}\text { Hypertension for several } \\
\text { years; terminal status } \\
\text { epilepticus }\end{array}$ & Abnormal & $\begin{array}{l}425 \mathrm{~g} ; \text {; left ventricle } \\
\text { slightly enlarged }\end{array}$ & - & $\begin{array}{l}\text { Usual, but no } \\
\text { definite } \\
\text { pyramidal } \\
\text { tract de- }\end{array}$ & $\begin{array}{l}\text { No material } \\
\text { available }\end{array}$ \\
\hline $\mathrm{C} 16$ & 29 & $\begin{array}{l}\text { Atrial fibrillation and } \\
\text { heart failure for } 2 \text { wk. }\end{array}$ & & $\begin{array}{l}310 \mathrm{~g} . ; \text { thrombus in left } \\
\text { ventricle and atrium }\end{array}$ & 一 & $\begin{array}{l}\text { generation } \\
\text { Usual }\end{array}$ & Fibrosis ++ \\
\hline $\mathrm{C} 17$ & 29 & & Abnormal & & - & $\begin{array}{l}\text { No material } \\
\text { available }\end{array}$ & $\begin{array}{l}\text { No material } \\
\text { available }\end{array}$ \\
\hline $\mathrm{C} 18$ & 30 & $4 \mathrm{mth}$. heart failure & Abnormal & $\begin{array}{l}640 \mathrm{~g} . ; \text { left and right } \\
\text { ventricles enlarged }\end{array}$ & & Usual & Fibrosis ++ \\
\hline $\mathrm{C} 19$ & 30 & $\begin{array}{l}\text { Terminal heart failure and } \\
\text { diabetic ketosis }\end{array}$ & Abnormal & No details known & $\begin{array}{l}\text { Ascites; pulmonary } \\
\text { oedema }\end{array}$ & $\begin{array}{l}\text { No material } \\
\text { available }\end{array}$ & $\begin{array}{l}\text { No material } \\
\text { available }\end{array}$ \\
\hline $\mathrm{C} 20$ & 31 & $\begin{array}{l}\text { Terminal virus infection, } \\
\text { atrial fibrillation, and } \\
\text { heart failure }\end{array}$ & Abnormal & $\begin{array}{l}420 \mathrm{~g} . ; \text { left and right } \\
\text { ventricles enlarged }\end{array}$ & & Usual & Fibrosis ++ \\
\hline $\mathrm{C} 21$ & 31 & No details known & Not taken & $360 \mathrm{~g}$; d dilatation of & - & Usual & Fibrosis ++ \\
\hline $\mathrm{C} 22$ & 31 & $\begin{array}{l}\text { Intermittent atrial fibrilla- } \\
\text { tion and heart failure } \\
\text { since age of } 27\end{array}$ & Abnormal & $\begin{array}{l}500 \mathrm{~g} . \text {; left and right } \\
\text { ventricles enlarged; } \\
\text { thrombus in both } \\
\text { atria }\end{array}$ & $\begin{array}{l}\text { Embolus in middle } \\
\text { meningeal } \\
\text { artery; kidney } \\
\text { infarcts }\end{array}$ & Usual & Fibrosis $t+$ \\
\hline $\mathrm{C} 23$ & 35 & $\begin{array}{l}\text { Terminal atrial fibrillation } \\
\text { and coma (? cause) }\end{array}$ & Abnormal & $\begin{array}{l}311 \text { g.; right ventricle } \\
\text { enlarged }\end{array}$ & & $\begin{array}{c}\text { No material } \\
\text { available }\end{array}$ & Fibrosis ++ \\
\hline $\mathrm{C} 24$ & 35 & $\begin{array}{l}2 \text { wk. chest pain and } \\
\text { dyspnoea }\end{array}$ & Not taken & $\begin{array}{l}504 \mathrm{~g} . ; \text { right and left } \\
\text { ventricles enlarged }\end{array}$ & $\begin{array}{l}\text { Congestion of } \\
\text { lungs }\end{array}$ & $\begin{array}{c}\text { No material } \\
\text { available }\end{array}$ & $\begin{array}{l}\text { No material } \\
\text { available }\end{array}$ \\
\hline $\mathrm{C} 25$ & 40 & $\begin{array}{l}\text { Possible subacute bacterial } \\
\text { endocarditis at } 35 ; \\
\text { terminal hemiplegia }\end{array}$ & Abnormal & $\begin{array}{l}\text { Thrombus in left } \\
\text { ventricle }\end{array}$ & & $\begin{array}{l}\text { No material } \\
\text { available }\end{array}$ & $\begin{array}{l}\text { No material } \\
\text { available }\end{array}$ \\
\hline C26 & 45 & $4 \mathrm{mth}$. heart failure & Abnormal & $\begin{array}{l}\text { Thrombus in left } \\
\text { atrium }\end{array}$ & $\begin{array}{l}\text { Gangrene of gut } \\
\text { due to arterial } \\
\text { obstruction }\end{array}$ & Usual & Fibrosis ++ \\
\hline C27 & 70 & $\begin{array}{l}\text { No cardiac symptoms; } \\
\text { terminal pneumonia }\end{array}$ & Abnormal & $\begin{array}{l}255 \text { g.; left ventricle } \\
\text { enlarged }\end{array}$ & $\begin{array}{l}\text { Bilateral bronchial } \\
\text { pneumonia }\end{array}$ & Usual & Fibrosis ++ \\
\hline
\end{tabular}

^ Where spinal cord changes are described as Usual, the appearances are those usually found in Friedreich's ataxia (see text). 
the development of progressive ataxia without remission, during childhood, adolescence, or early adulthood. In addition, the plantar responses were extensor, the tendon reflexes were diminished or absent, and there was postural and vibratory loss in the legs. In addition, some patients had a scoliosis and pes cavus. In all these cases the clinical diagnosis had been Friedreich's ataxia. In one additional case (C21) no clinical details were available. It was known that there had been progressive ataxia since childhood and the diagnosis of Friedreich's ataxia had been made. Both the heart and cord of this case showed the usual changes found in the other cases of Friedreich's ataxia.

Electrocardiograms from 24 patients were available for study. Extensive $T$ wave inversion in the left ventricular epicardial leads was seen in tracings from 20 patients. The tracing from one patient (C20) was taken shortly before death and showed only atrial fibrillation. The tracing from another patient (C4) showed very low voltage $T$ waves in left ventricular leads. The tracing from a further patient showed severe right ventricular hypertrophy and a deep wide $Q S$ in left ventricular leads. Only one patient (C6) had a normal tracing; and she was only 7 when the tracing was taken.

Spinal Cord. Sections from the spinal cord were stained with four stains-haematoxylin and eosin, van Gieson, Weil myelin stain, and Holmes axon stain.

Heart. Previously stained sections only were available from some cases. In others, blocks and/or unstained sections were available. Sections, having been cut if necessary, were stained with haematoxylin and eosin, van Gieson, and elastic stains.

The three whole hearts were all treated in an identical manner. After the heart had been weighed the main coronary arteries were carefully dissected off the heart, cut into suitable lengths, and labelled. After fixation they were embedded in paraffin and sections were cut at $5 \mathrm{~mm}$. intervals. Between 5 and 10 stained sections were mounted on each slide.

The heart was sliced at $1 \mathrm{~cm}$. intervals from apex to base. The slices were embedded in celloidin, and sections, $30 \mathrm{~m} \mu$ thick, cut. Some ventricular muscle from each heart was embedded in paraffin and thinner sections (20 $\mathrm{m} \mu$ thick) were cut.

The valves were inspected after most of the ventricular muscle had been removed. The atria were opened, the interatrial septum inspected, and pieces of both atria removed for histological examination.

The sino-atrial node was identified by the serial section method of Hudson (1963).

All material, apart from the whole slices of ventricular muscle, was embedded in paraffin. All sections were stained with haematoxylin and eosin and van Gieson. Sections of the coronary arteries and sino-atrial nodes were also stained with Moore's elastic stain. The sinoatrial node was also stained with Holmes nerve fibre stain. The transverse sections of the whole heart were also stained with Goldner's trichrome stain to show the distribution of fibrous tissue.

A careful study was made of the blood supply to the heart. The main coronary arteries were carefully examined and the findings were compared with the coronary arteries taken from two controls of the same age.

The small cardiac arteries were systematically examined in all the sections available from the 13 cases in which slides and/or blocks only were available. Three transverse sections from each complete heart were taken -9 sections in all. One section was chosen from the apex of the heart, one from the middle of the heart, and one from the base of both ventricles. The whole of each section was first scanned under the low power dissecting microscope. Grossly narrowed arteries were looked for and, if found, marked and counted.

One hundred consecutive small arteries from each of the nine transverse sections were then counted (900 arteries in all). A grid was superimposed upon the slide during counting, thus ensuring that arteries were not counted more than once. Narrowed arteries noted during the low power scan were deliberately avoided and were not counted again. Approximately equal numbers of arteries from the left ventricle, interventricular septum, and right ventricle were counted. Vessels were divided into three arbitrary sizes-500-1500 $\mathrm{m} \mu, 100-500$ $\mathrm{m} \mu$, and $100 \mathrm{~m} \mu$ or less. The total diameter of the artery, including its wall, was measured and compared with the diameter of the lumen. Thus, two arterial groups emerged-those in which the lumen diameter measured more than half the total vessel diameter (group A) and those in which the lumen diameter measured less than half the total vessel diameter (group B). Only vessels cut in true cross-section were measured. Where an artery had assumed an oblong shape, the longest diameter of the artery and its lumen was measured.

\section{RESULTS}

Spinal Cord. All sections of spinal cord showed degeneration in the posterior columns and in the direct spino-cerebellar tracts. All except one showed degeneration in the crossed cortico-spinal tracts. One (C15) did not show any cortico-spinal tract degeneration.

\section{Heart}

(a) Gross findings. The mean cardiac weight (19 hearts) was $453 \mathrm{~g}$. (range $255-730 \mathrm{~g}$.). This figure includes three hearts from patients of less than 20 years of age at the time of death. Thickening of the left ventricle was noted in most hearts. Nine hearts contained antemortem thrombus. In one case (C8) the left renal artery was occluded by antemortem thrombus, but no thrombus was found in the heart. In three cases antemortum thrombus was found in the heart and in a major artery. No heart showed any valvular abnormality or septal defect.

(b) Microscopical findings. Antemortem thrombus was noted in the cavity of three hearts, in 


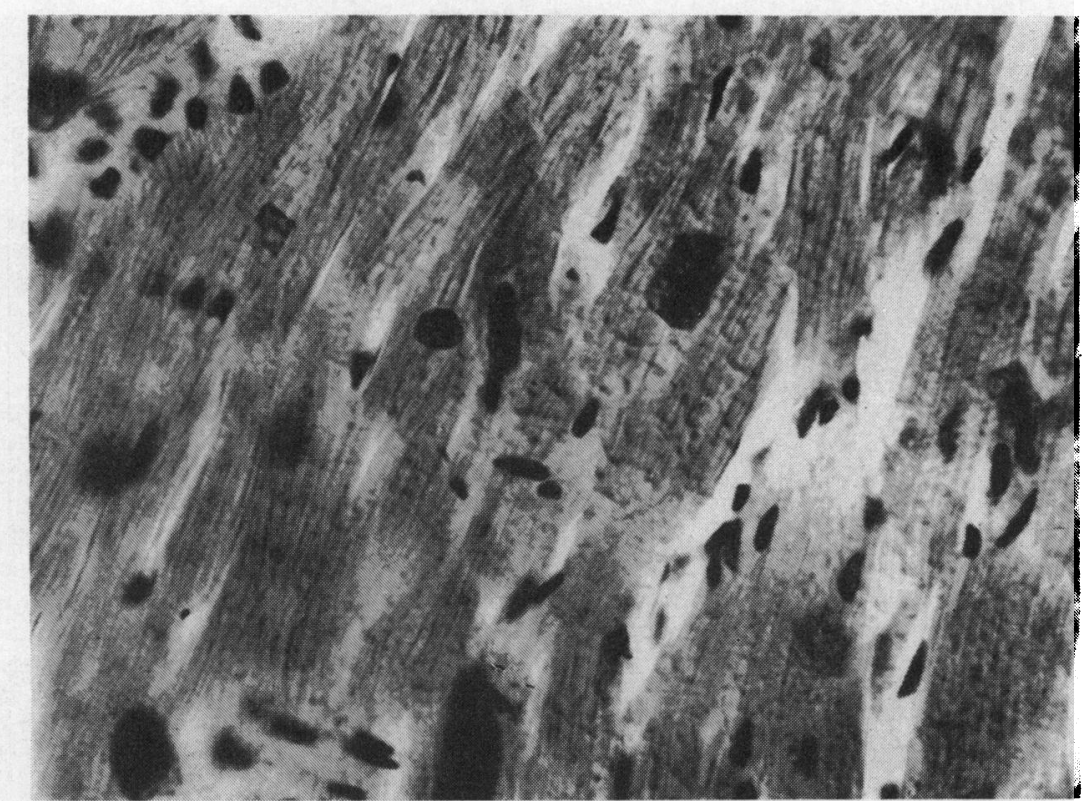

FIG. 1.-Case C10. Large and bizarre muscle fibre nuclei. $\quad(H$. and E. $\quad \times 395$.)

addition to those in which thrombus had been noted macroscopically.

The heart muscle of all cases showed conspicuous hypertrophy of fibres. Many of the muscle fibre nuclei were large and contained much darkly stained material (Fig. 1). Fatty infiltration was uncommon, being observed in large amounts in only two hearts (C14 and C26-Fig. 2).

All areas of heart muscle including the atria showed severe fibrosis. Thin strands of fibrous tissue were seen coursing between individual muscle fibres (Fig. 3). In places, the fibrous tissue had

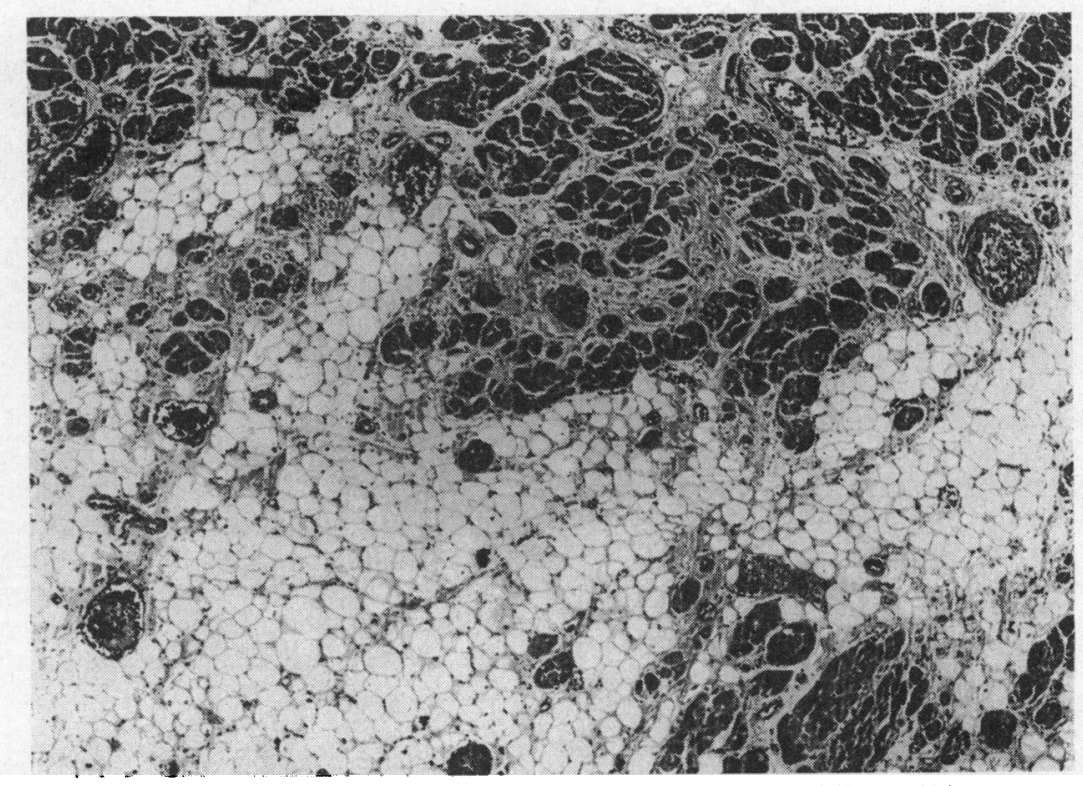

FIG. 2.-Case C26. Extensive fatty infiltration. (H. and E. $\times 40$.) 


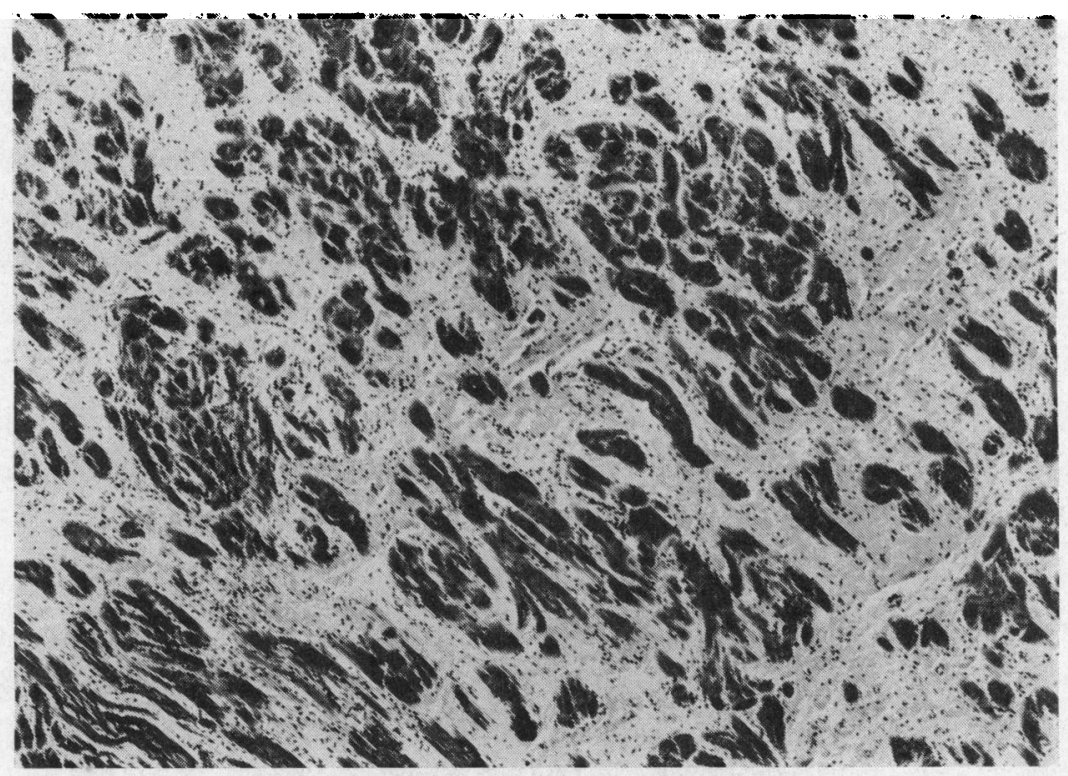

FIG. 3. Case C8. Severe interstitial fibrosis. (van Gieson. $\quad \times 40$.)

coalesced forming small scars. In some of these it appeared that muscle fibres had disappeared and had been replaced by fibrous tissue. A small amount of fibrous tissue was seen round blood vessels, but nowhere was this severe.

Scattered among the fibrous tissue were a moderate number of spindle-shaped fibroblasts. With the exception of the heart from $\mathrm{C} 10$ there was little cellular infiltration. One section from the heart of C26 showed a single collection of small round cells.

The heart from $\mathrm{Cl} 10$ was different from the others in that, in addition to the features common to all the hearts mentioned above, there were also many foci of active muscle necrosis (Fig. 4 and 5). These foci were seen both in the ventricles and in the intra-

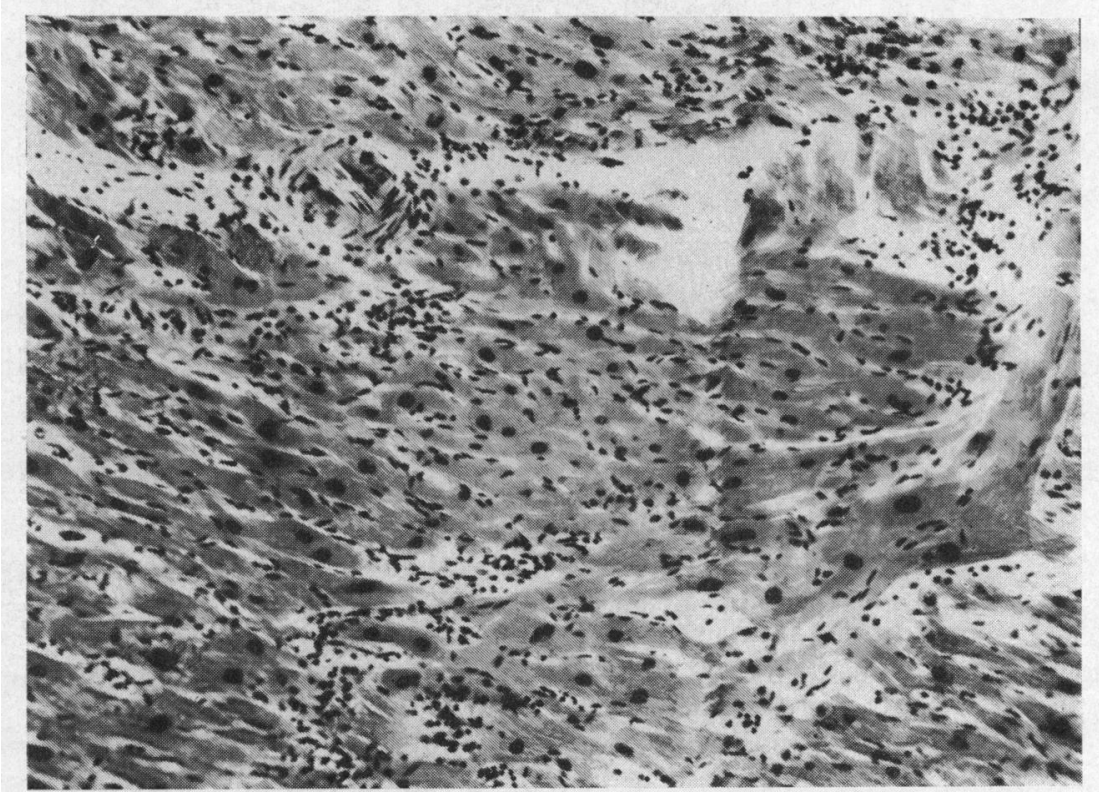

FIG. 4.-Case C10. Several foci of inflammatory cells and muscle fibre necrosis. (H. and E. $\times 96$. 


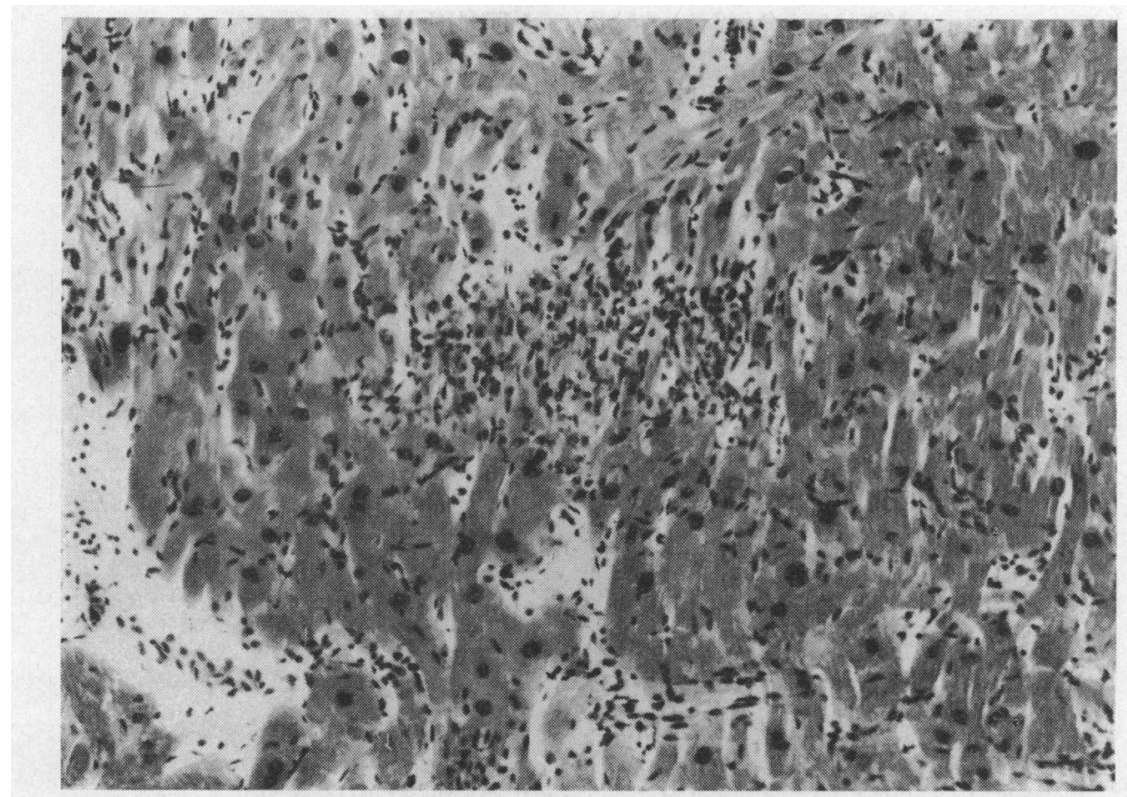

Fig. 5.-Case C10. Single focus of muscle fibre necrosis. (H. and E. $\quad \times 96$.)

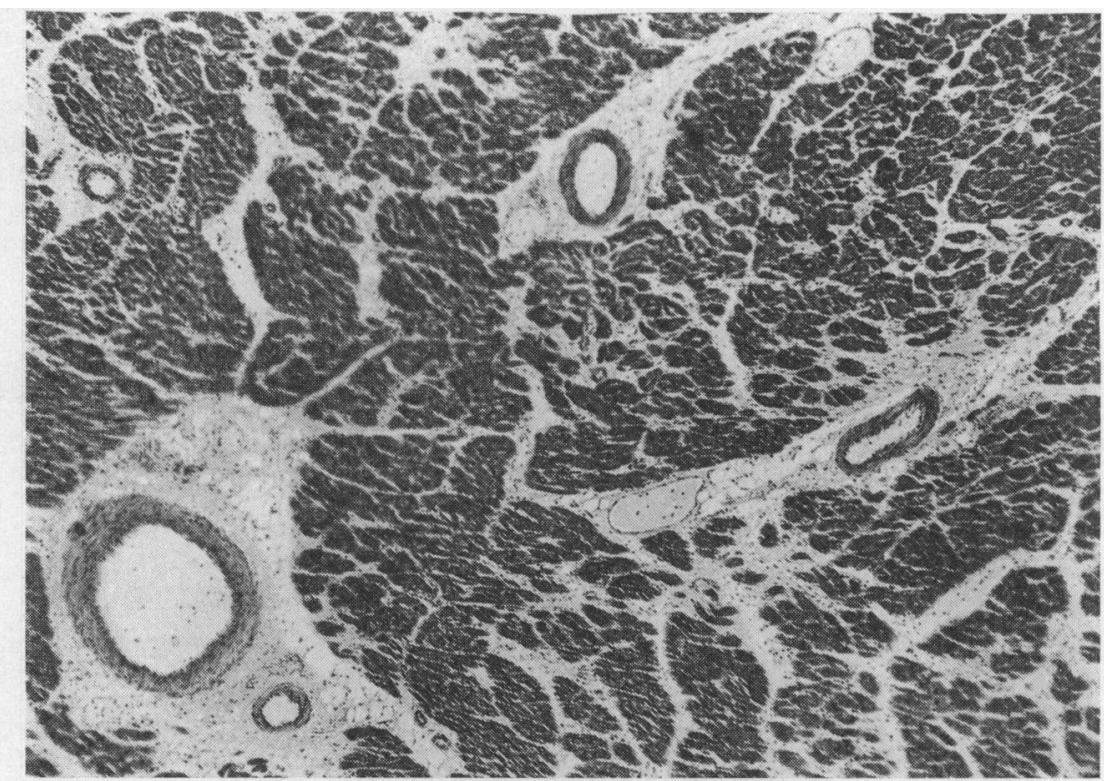

Fig. 6. - Case C14. Several normal small cardiac arteries. (H. and E. $\times 40$.)

ventricular septum, but they were most frequent in the latter situation. The foci comprised disintegrating muscle fibres surrounded by collections of cells which included a few polymorphonuclear leucocytes, an occasional mast cell, and several giant macrophages.

Examination of the sino-atrial nodes showed no obvious abnormality. Many apparently normal nerve fibres and ganglia were seen.

\section{Vessels}

(a) Main coronary vessels. All the main coronary arteries, including the two controls, showed some areas, at least, in which the intima was of 


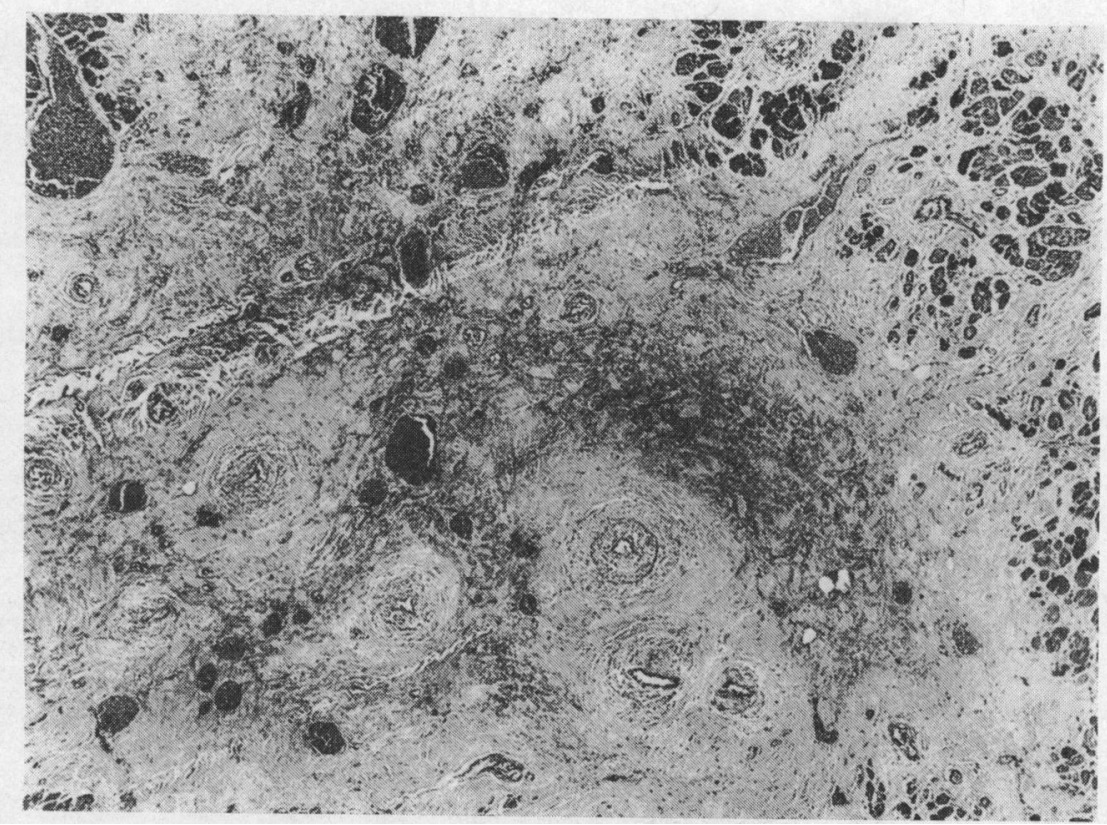

Fig. 7.-Case C14. Grossly scarred papillary muscle with many narrowed arteries. (H. and E. $\times 40$.)

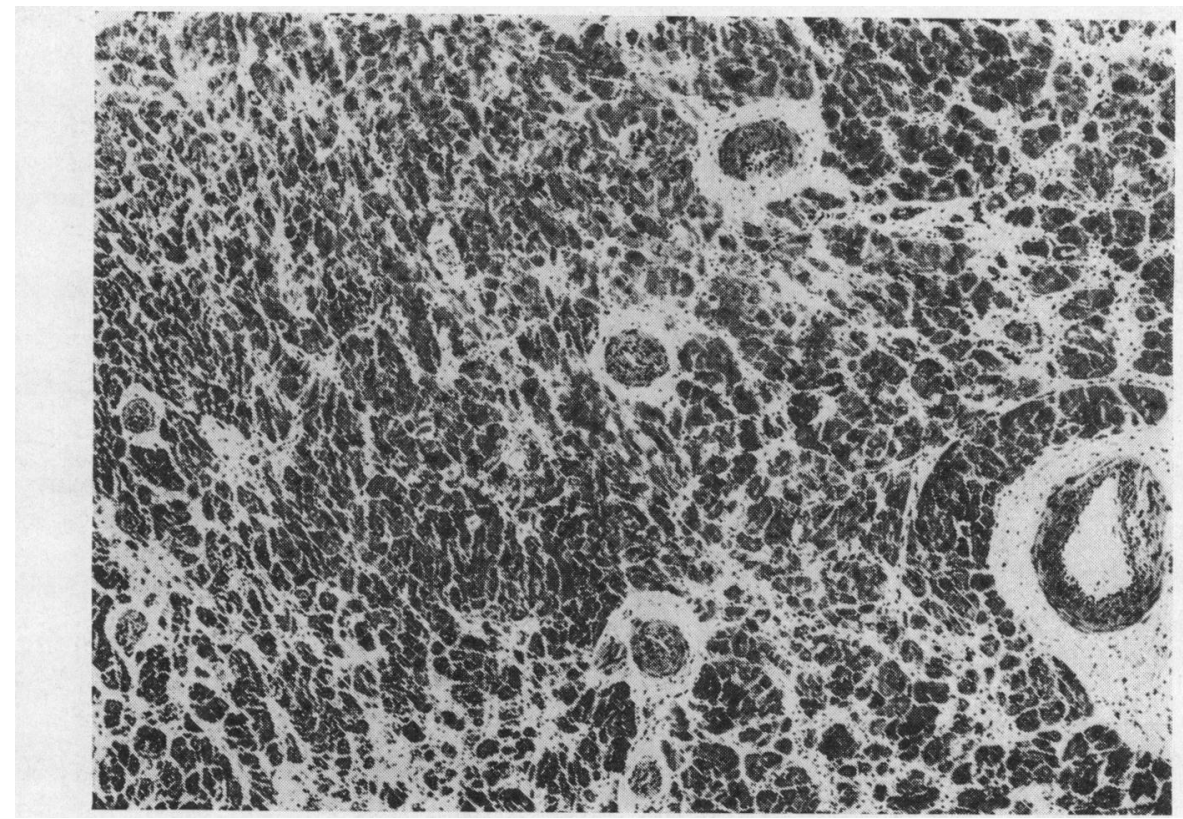

FIG. 8.-Case C8. Several narrowed arteries. (H. and E. $\times 40$.)

approximately the same thickness as the media. Several atheromatous plaques were present. No artery was occluded, and none showed gross narrowing. The internal elastic lamina frequently showed reduplication. (b) Small cardiac arteries. The great majority of small cardiac arteries appeared normal (Fig. 6). However, low power scanning of the heart sections showed narrowed arteries in one of the 3 standard sections taken from 2 hearts (C8 and C14, Fig. 7, 


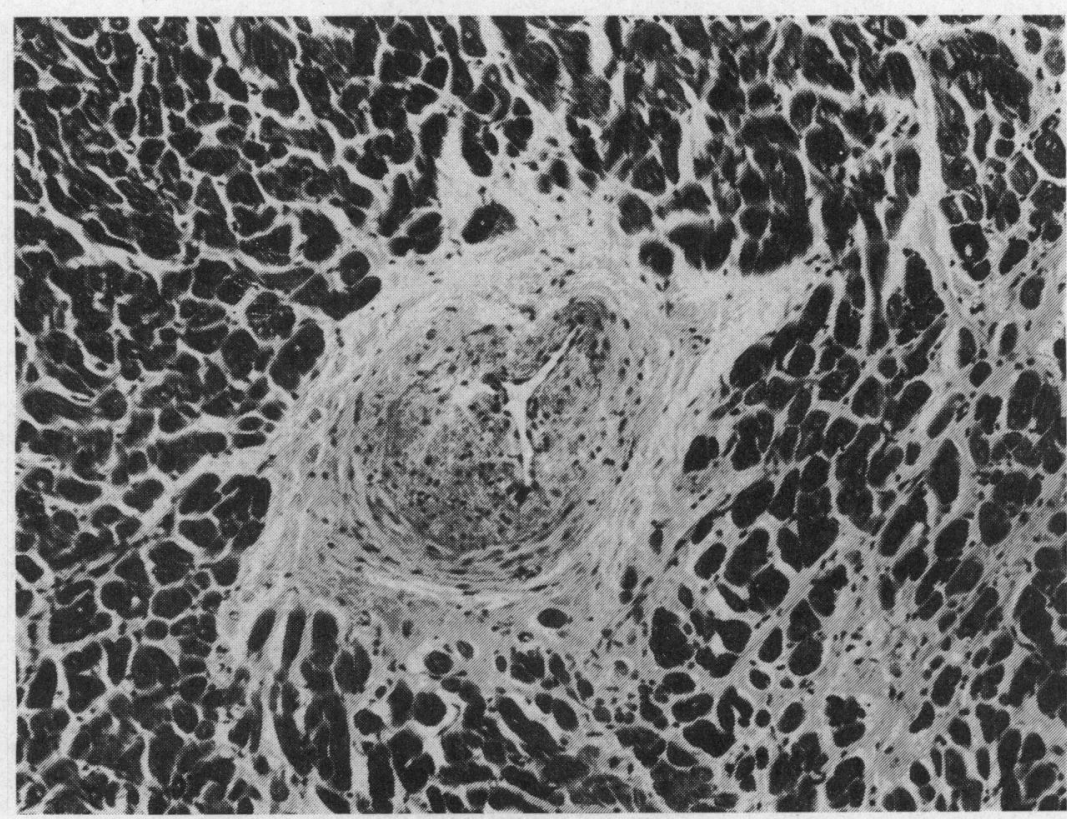

Fig. 9.-Case C14. Single grossly narrowed artery. (H. and E. $\quad \times 96$.)

8, and 9). No narrowed arteries were seen in any of the 3 standard sections of the third heart (C10), but another section did show 2 groups of narrowed arteries. In each of the relevant sections the narrowed arteries were clustered together in groups of between 8 and 14 arteries. These abnormal vessels were usually situated in the centre of a severely scarred papillary muscle. In each of the affected sections 2 groups of narrowed arteries were seen. The arteries were very often grossly narrowed, and in some instances the lumen had been totally obliterated.

The results of counting small cardiac arteries are given in Table II. It will be seen that only 9 per cent (80 arteries) of the 900 arteries fell into Group $\mathrm{B}$-having a lumen diameter less than half the vessel diameter. The majority of the arteries in Group B were not grossly diseased and only a few showed severe luminal obstruction.

The veins were mainly healthy. One vein from the atrial wall of C26 contained antemortem thrombus. The adjacent atrial appendage also contained antemortem thrombus.

\section{Discussion}

All the hearts examined in this study were abnormal. All showed the usual findings of muscle fibre hypertrophy and interstitial fibrosis. Only one (C10) showed evidence of active degeneration and necrosis of muscle fibres. This heart showed changes similar to those described by Russell (1946) in her Case 4.

TABLE II

TABLE SHOWING NUMBER OF SMALL ARTERIES WITH LUMEN DIAMETER LESS THAN HALF TOTAL ARTERIAL DIAMETER

\begin{tabular}{l|c|c|c|c|c|c}
\hline \multirow{2}{*}{$\begin{array}{c}\text { Diameter of } \\
\text { arteries }\end{array}$} & \multicolumn{2}{|c|}{ Case C8 } & \multicolumn{2}{c|}{ Case C10 } & \multicolumn{2}{c}{ Case C14 } \\
\cline { 2 - 7 } & $\begin{array}{c}\text { Group } \\
\text { A }\end{array}$ & $\begin{array}{c}\text { Group } \\
\text { B }\end{array}$ & $\begin{array}{c}\text { Group } \\
\text { A }\end{array}$ & $\begin{array}{c}\text { Group } \\
\text { B }\end{array}$ & $\begin{array}{c}\text { Group } \\
\text { A }\end{array}$ & $\begin{array}{c}\text { Group } \\
\text { B }\end{array}$ \\
\hline $\begin{array}{c}500-1500 \mathrm{~m} \mu \\
100-500 \mathrm{~m} \mu \\
<100 \mathrm{~m} \mu\end{array}$ & 17 & 0 & 43 & 1 & 16 & 0 \\
\hline Total & 174 & $\begin{array}{c}15 \\
71\end{array}$ & $\begin{array}{c}169 \\
54\end{array}$ & 19 & 74 & 7 \\
\hline Percentage & 262 & $38^{\star}$ & 266 & 34 & 292 & 8 \\
\hline
\end{tabular}

Group A. Lumen diameter greater than half the total diameter of the artery.

Group B. Lumen diameter less than half the total diameter of the artery.

$\star 13$ of these 38 arteries were grossly narrowed. 
The cases showed the typical neuropathological findings found in Friedreich's ataxia, namely degeneration of the posterior columns and direct spinocerebellar tracts and crossed cortico-spinal tracts. Only one case did not show corticospinal tract degeneration. Unfortunately, histological material from the heart of this patient was not available.

The author has been unable to find any reference to descriptions of cardiac pathology occurring in any of the conditions closely allied to Friedreich's ataxia, such as Roussy-Levi syndrome, familial spastic paraplegia, and peroneal muscular atrophy. Occasional clinical and electrocardiographic descriptions have, however, been made (Tyrer and Sutherland, 1961; Leak, 1961).

A recent study by the author (to be published) has shown that 56 per cent of 82 fatal cases of Friedreich's ataxia died with heart failure, and a further 17 per cent had cardiac symptoms before death. An electrocardiographic study by Thorén (1964) in Sweden showed that 92 per cent of 49 patients had an abnormal electrocardiogram. A study by the author of 191 patients showed that approximately 90 per cent had abnormal tracings. Our finding that 100 per cent of the 27 hearts examined were abnormal indicates that most, if not all, patients with classical Friedreich's ataxia have associated heart involvement. The author has been unable to find any detailed published account of normal cardiac histology in Friedreich's ataxia.

It is interesting to speculate whether the heart in patients with Friedreich's ataxia is normal during the early years of life, or whether it is abnormal from birth. Several authors have reported changing electrocardiogram patterns in Friedreich's ataxia (Boyer, Chisholm, and McKusick, 1962; Thorén, 1964). The present author has seen changing tracings in at least 35 patients-in many cases the electrocardiogram went from a normal to an abnormal pattern. The fact that heart failure rarely occurs under the age of 10 also seems to indicate that cardiac function is little impaired during the early years of life. On balance it seems probable that the heart becomes involved at about the same time as the nervous system. The active necrosis found in Case $\mathrm{C} 10$ of our series indicates that heart muscle degeneration may continue for many years (she had had angina for at least 12 years). As yet it is not possible to say whether the heart muscle degeneration continues throughout adult life, or whether it "burns itself out".

What then is the significance of the coronary artery narrowing reported now and previously? Previous workers have given little indication of the proportion of small cardiac vessels that are nar- rowed. However, James and Fisch (1963) wrote that "diseased arteries were apparent in almost every area examined". The present study appears to be the first in which any sort of quantitative assessment of small cardiac vessel disease has been undertaken. The finding that only 9 per cent of 900 arteries had a lumen diameter of less than half the total arterial diameter indicates that cardiac artery disease is probably not responsible for the extensive muscle fibrosis which is observed. Furthermore, the finding of small patches of active muscle necrosis, without associated nearby artery pathology, argues against an ischaemic basis for the heart disease.

What then is the cause of the small artery disease which does occur? Ivemark and Thorén (1964) postulate that the changes are non-specific and are a reaction to atrophy and involution of cardiac muscle. The opposite view is taken by James and Fisch (1963), who feel that the arterial changes are primary and that fibrosis occurs secondarily. James (1964) has further amplified his findings, and reports medial necrosis leading to luminal encroachment of small cardiac and pulmonary arteries also in Marfan's syndrome, progressive muscular dystrophy, primary pulmonary hypertension, and the syndrome of congenital deafness with fainting attacks and sudden death. The present study appears to be much in favour of the view that the arterial narrowing is a secondary phenomenon-probably occurring as a reaction to the extensive atrophy of cardiac muscle which has occurred. It should be noted that in most of the areas in which narrowed arteries were found, in our material, there was also extensive replacement of muscle by fibrous tissue.

\section{SUMMARY}

This paper reports the cardiac findings in 27 cases of Friedreich's ataxia. Material from 16 hearts was available for histological examination, and included three complete hearts.

All hearts showed extensive interstitial fibrosis with considerable focal degeneration of muscle fibres. One heart showed extensive active muscle necrosis. The main coronary arteries showed no gross disease. Each of the three complete hearts examined showed areas in which gross narrowing of small cardiac arteries had occurred. However, careful counting of arteries of different diameters indicates that the vast majority of cardiac arteries are not obviously narrowed. It is suggested that such arterial narrowing that does occur is secondary to involution of cardiac muscle. It is thought unlikely that the diffuse myocardial fibrosis occurs as a result of the vessel changes. 
My thanks are due to many physicians, neurologists, and pathologists throughout the country for giving or lending their material. My particular thanks are due to Dr. J. Trevor Hughes for his help and encouragement, to Dr. Trevor Parry for help with the photographs, and to Mr. Ron Beezley for technical assistance. I acknowledge, with thanks, financial assistance given by the Muscular Dystrophy Group and the Friedreich's Ataxia Group.

\section{REFERENCES}

Boyer, S. H., Chisholm, A. W., and McKusick, V. A. (1962). Cardiac aspects of Friedreich's ataxia. Circulation, 25, 493.

Graham, G. R. (1964). In CIBA Foundation Symposium: Cardiomyopathies, pp. 358-375. Ed. by G. E. W. Wolstenholme and M. O'Connor. Churchill, London.

Hudson, R. E. B. (1963). The human conducting-system and its examination. f. clin. Path., 16, 492.
Ivemark, B., and Thorén, C. (1964). The pathology of the heart in Friedreich's ataxia. Acta med. scand., 175, 22.

James, T. N. (1964). An etiologic concept concerning the obscure cardiomyopathies. Progr. cardiovasc. Dis., 7, 43.

-, and Fisch, C. (1963). Observations on the cardiovascular involvement in Friedreich's ataxia. Amer. Heart F., 66, 164.

Leak, D. (1961). Paroxysmal atrial flutter in peroneal muscular atrophy. Brit. Heart f., 23, 326.

Nadas, A. S., Alimurung, M. M., and Sieracki, L. A. (1951). Cardiac manifestations of Friedreich's ataxia. New Engl. F. Med., 244, 239.

Russell, D. S. (1946). Myocarditis in Friedreich's ataxia. f. Path. Bact., 58, 739.

Thorén, C. (1964). Cardiomyopathy in Friedreich's ataxia. Acta paediat. (Uppsala), 53, Suppl. 153.

Tyrer, J. H., and Sutherland, J. M. (1961). The primary spino-cerebellar atrophies and their associated defects, with a study of the foot deformity. Brain, 84, 289.

Urich, H., Norman, R. M., and Lloyd, O. C. (1957). Suprasegmental lesions in Friedreich's ataxia. Confin. neurol. (Basel), 17, 360. 